\title{
Perceptions of Inmates on Social Work Intervention in Osun State Prisons, Nigeria
}

\author{
Eyitayo Olufunmilayo Akinyemi, Ph.D \\ Department of Adult Education \\ Adekunle Ajasin University \\ Akungba Akoko, Ondo State, Nigeria \\ E-mail:drumsbuy@gmail.com
}

\begin{abstract}
The study investigated the inmates on social work intervention in Osun State prisons, Nigeria. The specific objectives of the study identified the age range of the inmates, inmates' perception towards a societal valued life, level of engagement in skill acquisition and formal education, attitude of government and prison service employees towards inmates' reformation. The study adopted descriptive research design. The sample consisted of 88 inmates randomly selected from the 880 inmates and eight (8) warders from Ilesa prison yard. The research instrument was a close ended questionnaire and focus group discussion. Data obtained were analysed using percentages and frequency counts. Results showed that inmates' ages range mostly between 2I and 25 years. Findings also showed inmates perceived they could still live a good and societal acceptable life; the societal services rendered to them were good to an extent that they had positive attitudes towards skill acquisition and formal education; inmates were satisfied with the services rendered by prison workers and welfare provisions from the government. Findings concluded that the inmates believed they could still live an acceptable life during and as an ex-convict. The study recommended that individual inmate could be tailored and encouraged on the need to better their lives in the prison yard and become acceptable and selfreliant ex-convict.
\end{abstract}

Keywords: Inmates, Intervention, Perceptions, Prison, Social Work

\section{Introduction}

Nigeria prison services operate as government agency in Nigeria, with the headquarter of the institution in Abuja. It operates prisons and is being supervised by the Ministry of Interior. Merriam Webster dictionary defined prison as a place of confinement especially for law breakers, an institution for confinement of persons convicted of serious crimes usually under state control, and a building where people accused of crime are kept before their trials. The researcher sees a prison as a place where adult males and females are confined so as to allow peace to reign in their lives and the society at large, a way of making them realize their mistakes, feel sober, adjust to their new environment so as to become a better person later in life after due parsystem which they might have undergone before leaving the prison environment.

Laws are made by a society to curb different forms of misbehavior that could be exhibited and experienced by every society, is known for experiencing members committing crime. These offences range from fighting, stealing, killing ,armed robbery, tugery, bulling, cultism, bribery and corruption, money laundering, child trafficking, child abuse, domestic violence, bombing, oil bunkering, kidnapping, illegal protesting, rapping, we also have terrorists like; Islamic Boko Haram, Fulani herdsmen and many others.(Oloruntegbe, 20I4).

The prison services through social work are expected to fulfill the objectives of prison as a place of rehabilitating, reformatting and re-integrating prisoners. Rehabilitating criminals as one of the activities of social work is to restore them with necessary education and training which will make their reintegration into the society a successful effort. This is the reason for encouraging prisoners to take part in different welfare opportunities available for them in the prison yard. Prisoners have the opportunity of learning different skills and registering for different levels of educational pursuit.

Prison as a place of reformation is the attempt to improve the conditions of inmates inside prison and establish a more effective peril system. Reforming prisoners is having access to legal counsel and family, and proactive security against violence. The goal of reformation is to repair the deficiencies in the individual inmate and return them as productive members to reintegrate them into the society. Examples are education, work skills, learning how to treat others with respect, and self-discipline. Services being rendered to inmates have not been adequate enough in Nigeria prison, the reason why many ex-prisoners are still involving themselves in crimes that initially sent them to prison. The prison service was established to ensure criminals are empowered constitutionally as posited by Adetula, Adetula and Fatusin (2010) (cited in Oroleye, 2018)

- For safe custody, keep convicted prisoners

- Inmates awaiting trial to be kept in custody until their appearance as demanded by the law courts. 
- Offenders are punished as directed and pronounced by law courts.

- Reformation of the convicted prisoners should commence.

- The rehabilitation and reintegration of prisoners who have completed their sentences in the prison should proceed.

Some people felt prisons exist so as to punish wrongdoers, to remove the danger they could later pose to the society, and that prison helps to reform the characters of people who break the law of the society, and keeping criminals in prison is necessary to prevent them from committing more crimes in the society, (Guardian 2008).

The Saturday punch (2015) is of the view that when long term imprisonment is used, in such prison, lack of food, sanitation, and medical care causes wide spread diseases and death.

The Ilesa prison yard is one of the prisons in Nigeria. There are two prisons in Osun State; they are Ilesa and Ile-Ife prisons out of the 240 prisons in Nigeria. Ilesa prison had a total of 880 prisoners. 848 of them were men and 32 women as of September 20I8. Eighteen (I8) prisoners were lifers, I72 convicted and 628 were awaiting trials. The Ilesa prison has 4I cells, which was expected to accommodate 588 inmates, so also Ile-Ife prison has six (6) modern cells that should have 160 inmates instead of the present 370 inmates, although Ile-Ife prison has no female inmates. The issue of overcrowding is not peculiar with Osun State prisons alone but a common issue in Nigeria prisons, which could be assumed to be a result of long sentences being given to violent crimes, and long awaiting periods to court for trials. Over-populated beyond these capacity designated for them, the federal and state governments had been charged to solve this problem.

Obioha (20I I) challenges the reforms in the Nigerian prisons system, that there should be an institutionalization of decongestion committee to be headed by the Chief Judge of each state and a prerogative of mercy by the head of state of federation. In each state they are expected to function in the following areas:

- Frequent visitations to be paid to the prisons to see their current situations.

- Occasionally review cases of suspected and convicted inmates on trials and see to their release as expected.

- Amnesty are to be granted to prisoners that deserve them.

Obioha (1995) observed the problem of overcrowding in Nigeria prisons had been before the colonial rule which had been a recurring administrative problem and has been causing some killer diseases, inmates experience air born infections, infectious disease such as skin scabies and bilharzias; HIV/AIDS, asthma, tuberculosis, liver sclerosis, sepsis and dysentery while there were no standard hospitals, qualified doctors nor drugs to care for sick inmates. This was the assertion of some inmates of Agodi prison, Ibadan (Saturday punch, 2017) the prison has the capacity to accommodates, with 88 percent of the number constituting the inmates awaiting trial, complained of overcrowding in the cells, more than I40 prisoners with HIV and even tuberculosis living with others. The prison has no guarantee facility and capacity to isolate the inmates contagious diseases, while inmates live without the assurance of existing the next day, they buy drugs themselves as the officials always tell them there was no money to buy drugs or treat the inmates, while many inmates buy drugs for fellow prisoners. Many inmates died of contagious diseases.

The controller of Agodi prison, Oladipo (Saturday Punch, 2017) claimed that the prison authority is taking the health care of inmates seriously as the federal government was working hard to ensure that inmates are given good medical care, also that the prison clinic has a medical doctor being assisted by nurse. On serious cases, the inmates are transferred to Catholic hospital, Oluyoro or University College Hospital, Ibadan,. Oladipo further explained that the federal government had begun the construction of another prison yard at Olomi area of Ibadan, which can accommodate up to 5,000 inmates.

The researcher found out that at Ilesa prison yard, as at 2018 no frequent outbreak of disease as the cells is being fumigated regularly. There is a single cell where they isolate any inmate with special disease. If an inmate does not have money to buy drugs, will go to the welfare section to call the members of the family through the registered number in the prison in order to help them get drugs of recent, there was no record of death among the inmates. Claimed that drugs were distributed to all the prisons in the country by the minister of interior, while Non-governmental organisations and religious bodies pay the medical bills of some of the inmates. For example, at the Agodi minimum security prison, Ibadan, the inmates and families of the diseased person called on the government concerning the poor health care system of the prison yard, where inmates buy drugs for their fellow inmates and even share cells with T.B and HIV patients, while some inmates had no access to medical treatment and eventually died of Hepatitis B, liver sclerosis, sepsis and dysentery. (Daily punch, 2017).

The Chief Judge of Oyo State, Muntar Abimbola, said the release of inmates was within his power, he has to visit the prison and review the progress of cases of awaiting trial inmates in order to ensure they are tried on time (Saturday Punch, 2018), Amnesty is being granted as a statutory provision which is expected to be done frequently and get the prison decongested which should also be attributed to long sentence being given to violent crimes. Prisoners who did well could be released early to decongest the cells. The Oyo State Governor, Abiola Ajimobi granted amnesty to 18 convicted inmates. The Chief Judge of Oyo State, Abimbola M. granted amnesty to 84 inmates after reviewing their cases (Saturday Punch, 2018). Also at Agodi prison, Ibadan, 67 inmates that have stayed longer than expected were released, ten inmates were released because of the bad condition of their health with cases of chronic renal disease, HIV/AIDS, tuberculosis and asthma, seven released because they had no case to answer. Oladipo (Saturday punch, 2018), this was done based on the agreement between the Nigeria Bar Association and the Nigeria Medical Association. 
Some convicted inmates believed being prisoners does not indicate the end of their lives. They believed they could be useful for themselves and other members of their societies later in life. The lifer among the prisoners who had additional educational qualification hoped they would be granted amnesty thereby using their certificates to develop their communities. The inmates believed they would still live a societal valued life.

The Daily Punch (2018) gathered information from life prisoners pilling up degrees. An inmate, Kabiru did not hide his identity, claimed the prison yard situation would not prevent him from achieving his educational goals. A lifer said "my degree will never be useless" many inmates serving life sentences have been acquiring university degrees as much as possible, like Kabiru, who attended the National Open University of Nigeria was happy to obtain master's degree in Business Administration, he said "he would prefer to teach at the basic level so as to impact his knowledge in the younger generation". He further stressed:

"I would not leave the way I came

I must be better

I would not bother about stigma because I do not look down on myself.

If I feel bad for myself, people will also feel bad for me

I would let people know why I am better than any other graduate there with the same degree as mine

Prison experience has not only shaped my thinking and moral values but has taught me to appreciate everything in life."

Although, the prison service in Nigeria and other parts of the world are to protect their society through deterrence, rehabilitation, reformation, and retribution of prisoners convicted (Oroloye, 20I0), but there had been complaints about the social work services in Nigeria prisons, thus this paper is particular about the perceptions of inmates at Ilesa prison on their social work intervention.

\section{Literature Review}

Nigeria is recording a high population of prisoners to be youths, this has been their inability to get someone or money to support them, thus forcing them to remain in prison for a long time, this has been the view of Kabir, (2019). Some convicted inmates who were lifers engaged themselves in formal education claiming they believed could gain freedom later in life. This was the assertion of Kabiru (2017) who came into prison as a holder of Secondary School Certificate, later became a holder of Master Degree in Business Administration. Prison inmates are expected to involve themselves in acquisition of skills depending on their areas of interest.

The vocational skills available in most of our prisons in Nigeria according to Talba (2015) are hair dressing, knitting, dress making, pomade and soap making, laundry and dry cleaning services, metal work, brick-laying and agro-based skills acquisition programmes. The availability of resource persons and finance always determine the type of skills the inmates will be able to acquire. These services available to fulfill according to Tenibaije (2010) in Abubakar \& Abba (2018) the United Nations' Standard Minimum Rules for the treatment of Prisoners (UNSMRETP) 7I (3) Rule, that 'sufficient work of a useful nature shall be provided to keep prisoners actively employed for a normal working day"

Ex-offenders often lack the skills, knowledge and training to support them when they return to their different societies. Davis; Steele; Bozick; Williams; Turner; Miles; Saunders; \&Steinberg (2014) also observed on an average, inmates who took part in correctional education programmes do not always offend and be sent back to the prison compared with released inmates who did not participate in correctional education, but due to lack of source of income are forced to commit crime that will send them back to the prison yard.

The establishment of prison yard is to implement different programmes that are interesting to inmates like remedial and adult education, vocational training, skills acquisition, recreational, attitudinal change, religious instructions and rehabilitating inmates into their society after they might have been released from their jail terms (Daramola, 2004). Criminals are able to be rewarded with training, education and other items which would not have been available to them if they have not committed crimes and found themselves in the prison yard, this was the assertion of Kabiru (2012) that if he had not committed crime, he would not have been able to get to his present level of academic achievement. Rand (2013), observed it is cheaper to reform and educate prisoners, and that prisons with education programmes have fewer violent incidents.

Every prisoner is entitled to programmes that are targeted at reforming them. The human value of a society will be reflected on the way they treat their convicted criminals, thus it is necessary they are provided with all the necessities of life like other members of the society (Mc clary, 2003). Thus, Clemens (2003) felt inmates are entitled to safe and adequate shelter, clothing, nutritious food and prompt medical attention, and that the prison environment should reflect what the society want inmates to be after their release. Schiraldi (2003) was of the view that having criminals in prison is punishing them and returning 
them to the society worse than before sending them to the prison, he felt the main target should be helping inmates turn their lives to be better.

\section{Research Questions}

- What was the age range of the inmates at the prison yard?

- What were the perceptions of inmates towards societal valued life?

- What were the perceptions of inmates towards skills acquisition?

- What were the perceptions of inmates towards formal and literacy education?

- What were the attitudes of government and prison service employees towards inmates' welfare?

\section{Methodology}

The total population (880) of the prison inmates in Ilesa prison yard selected for the study constituted the study population. Ten percent of the 880 prison inmates who were mentally stable were selected for the study.

In order to gather first-hand information, the respondents were given open-ended and close-ended questions. With due permission and cooperation of prison officials, the administrations of the questionnaire were done by the researcher. Section (A) of the questionnaire contained questions on their sex and age. Section (B) was close-ended questions on inmates' perceptions towards societal valued life; skill acquisition opportunities that was available; opportunities to formal education and the attitude of government and prison service employees towards inmates' welfare. The researcher visited the prisoners at the approved and appropriate time in order to adhere strictly to the regulations of the prison. Under the supervision of prison welfare officer, inmate that could fill the questionnaire were asked to do it while some were guided in filling the questionnaire. Eighty eight (88) questionnaires were given out, while only (66) copies of the questionnaire administered on the inmates were returned and being correctly filled. These (66) copies were used to analyze data for this study. Information was also collected from prison officials. The researcher also made use of secondary data records from Nigerian prisons service, magazines and journals.

\section{Results}

\section{Research Question I: What is the age range of the inmates at Ilesa prison yard?}

Table I: Frequency Distribution showing Respondents' Personal Information

\begin{tabular}{llrr}
\hline Factors & Options & Frequency & $\%$ \\
\hline \multirow{2}{*}{ Gender } & & & \\
\cline { 2 - 4 } & Male & 59 & 89.4 \\
\cline { 2 - 4 } & Female & 66 & 10.6 \\
\cline { 2 - 4 } Age & Total & 12 & 18.2 \\
\hline & $18-20$ years & 19 & 28.8 \\
\hline & $21-25$ years & 15 & 22.7 \\
\hline & $26-30$ years & 14 & 21.2 \\
\hline $31-35$ years & 3 & 4.5 \\
\hline & $36-40$ years & 66 & 100.0 \\
\hline & 40 years and above & 3.5 \\
\hline
\end{tabular}

The table revealed that the sampled inmates consist of male and females. This was such that $89.4 \%$ were males, while I0.6\% were females. It was also observed that $28.8 \%$ were within the age range of $2 \mathrm{I}$ and 25 years, while $22.7 \%$ were within the age range of 26 and 30 years. The study revealed that most of the inmates were youths. 


\section{Research Question 2:What were the perceptions of inmates towards a societal valued life?}

Table 2: Frequency and Percentage summary on the perceptions of inmates towards a societal valued life

\begin{tabular}{|c|c|c|c|c|}
\hline Items & Responses & & & \\
\hline & & Yes & No & Total \\
\hline \multirow[t]{2}{*}{ One could read and write. } & Frequency & 60 & 6 & 66 \\
\hline & $\% 90.9$ & & 9.1 & 100 \\
\hline \multirow{4}{*}{$\begin{array}{l}\text { Do you agree that you are an important } \\
\text { person in the society? } \\
\text { Do you agree that one's life could be } \\
\text { reformed, while here? }\end{array}$} & Frequency & 63 & 3 & 66 \\
\hline & $\%$ & 95.5 & 4.5 & 100 \\
\hline & Frequency & 54 & 12 & 66 \\
\hline & $\%$ & 81.8 & 18.2 & 100 \\
\hline \multirow{2}{*}{ Average Total } & Frequency & 59 & 7 & 66 \\
\hline & $\%$ & 89.4 & 10.6 & 100 \\
\hline
\end{tabular}

Field Study, 2018

From the observed distribution, Findings revealed $90.9 \%$ respondents claimed they could read and write, while $9.1 \%$ could not. $95.5 \%$ respondents agreed they are important persons in the society, while $4.5 \%$ disagreed with the statement. Also, $8 \mathrm{I} .8 \%$ of the respondents agreed that their lives could be reformed in the prison yard, while $18.2 \%$ had contrary opinion.It could be concluded based on the average summary that inmates perceived that they could still live a good and societal acceptable life even with the experience of the prison. This was such that $89.4 \%$ ofthe respondents confirmed their perceptions of inmates living a societal valued life as ex-convict, while I0.6\% did not agree.

\section{Research Question 3: What is the perception of inmates towards skill acquisition?}

Table 3: Frequency and Percentage summary on the perception of inmates about skill acquisition

\begin{tabular}{|c|c|c|c|c|}
\hline \multirow[t]{2}{*}{ Items } & \multicolumn{4}{|c|}{ Response } \\
\hline & & Yes & No & Total \\
\hline \multirow[t]{2}{*}{ Are you learning any skill here? } & Frequency & 34 & 32 & 66 \\
\hline & $\%$ & 51.5 & 48.5 & 100.0 \\
\hline \multirow{4}{*}{$\begin{array}{l}\text { Do you have enough, and relevant equipment to } \\
\text { learn the skill here? } \\
\text { Have you been practicing the skill before coming } \\
\text { here? }\end{array}$} & frequency & 36 & 30 & 66 \\
\hline & $\%$ & 54.4 & 45.5 & I00.0 \\
\hline & Frequency & 29 & 37 & 66 \\
\hline & $\%$ & 43.9 & 56.1 & 100.0 \\
\hline \multirow{2}{*}{$\begin{array}{l}\text { Do you intend using the skill (If learnt) after leaving } \\
\text { this place? }\end{array}$} & Frequency & 59 & 7 & 66 \\
\hline & $\%$ & 89.4 & 10.6 & 100.0 \\
\hline \multirow{2}{*}{$\begin{array}{l}\text { Do you feel the skill (If learnt) could sustain you } \\
\text { and the members of your family? }\end{array}$} & Frequency & 49 & 16 & 66 \\
\hline & $\%$ & 74.2 & 25.8 & 100.0 \\
\hline \multirow{2}{*}{$\begin{array}{l}\text { Do you feel the skill (If learnt) could help in the } \\
\text { development of Nigeria? }\end{array}$} & Frequency & 47 & 19 & 66 \\
\hline & $\%$ & 71.2 & 28.8 & 100.0 \\
\hline \multirow[t]{2}{*}{ Averaged Total } & Frequency & 52 & 14 & 66 \\
\hline & $\%$ & 78.8 & 21.2 & 100.0 \\
\hline
\end{tabular}

It was observed that several skills were acquired by inmates and these include: art work, bag making, computer training, carpentry, photography, tailoring, barbing and shoe making. It was also observed that $54.4 \%$ of the respondents were of the opinion that there were enough, and relevant equipment to learn such skill there. Findings revealed that $5 \mathrm{I} .5 \%$ of the respondents indicated that they are learning skills in the prison, while $48.5 \%$ does not. This implied that a large proportion of prison inmates do engage in the learning of any form of skill. Among those that learnt one form of skill, it was observed that majority of them have been practicing the skill before coming to the prison via conviction. This was such that $43.9 \%$ affirmed that they had been practicing the skill before. Also, 89.4\% of the respondents indicated that they intend using the skill learnt after leaving the prison, while $10.6 \%$ said contrary, it was noted that $74.2 \%$ of the respondents were of the opinion that they feel the skill could sustain them and the members of their family after leaving the place if they learnt it. Lastly, (7I.2\%) respondents indicated their support on the view that they feel the skill could help in the development of Nigeria. Conclusively, 
this showed that inmates have a positive attitude towards skill acquisition with $78.8 \%$ confirming it, while $2 \mathrm{I} .2 \%$ did not. Showing that the inmates intend using the skills after their release.

\section{Research Question 4: What is the perception of inmates towards formal and literacy education?}

Table 4: Frequency and Percentage summary on the perception of inmates towards formal and literacy education

\begin{tabular}{|c|c|c|c|c|}
\hline \multirow[t]{2}{*}{ Items } & \multicolumn{4}{|c|}{ Response } \\
\hline & & Yes & No & Total \\
\hline \multirow[t]{2}{*}{ Were you a student before coming here? } & Frequency & $5 \mathrm{I}$ & 15 & 66 \\
\hline & $\%$ & 77.3 & 22.7 & 100.0 \\
\hline \multirow[t]{2}{*}{ Do you intend going back to school? } & Frequency & 53 & 13 & 66 \\
\hline & $\%$ & 80.3 & 19.7 & 100.0 \\
\hline \multirow[t]{2}{*}{ Are you preparing for any examination here? } & Frequency & 32 & 34 & 66 \\
\hline & $\%$ & 48.5 & 51.5 & 100.0 \\
\hline \multirow[t]{2}{*}{ One is interested in improving one's literacy } & Frequency & 39 & 27 & 66 \\
\hline & $\%$ & 59.1 & 40.9 & 100.0 \\
\hline \multirow[t]{2}{*}{ Averaged Total } & Frequency & 44 & 22 & 66 \\
\hline & $\%$ & 66.7 & 33.3 & 100.0 \\
\hline
\end{tabular}

Field Study, 2018

The result indicated that majority of the respondents (90.9\%) affirmed that one could read and write as an individual, while 9.1\% felt contrary. In addition, $95.5 \%$ of the respondents agreed that they are important persons within the society. Lastly, majority of the respondents (8I.8\%) also affirmed that one's life could be sharpened in the prison, while I8.2\% felt contrary.

From the observed distribution, it could be summarized based on the average summary that inmates perceived that they could still live a good and societal acceptable life even with the experience of the prison. This was such that $89.4 \%$ of the respondents confirmed their perception of inmates living a societal valued life, while $10.6 \%$ did not. The test on statement regarding inmates' perception towards education generally were presented in Table 5 and it was observed that $77.3 \%$ affirmed that they were student before coming here, while $22.7 \%$ were not. it was also noted that majority, even including those that were not in school before (80.3\%) intend going back to school after leaving the prison, while $19.7 \%$ are not intending to do so. Further findings showed that $48.5 \%$ of the respondents are preparing for examinations, while $51.5 \%$ said they were not.

The average total proves that most of the respondents $(66.7 \%)$ had positive perceptions toward education, while $33.3 \%$ indicated negative perception towards formal and literacy education.

\section{Research Question 5: What is the attitude of government and prison service employees (Warders) towards the welfare of the inmates?}

Table 5: Frequency and Percentage summary on the attitude of government and prison service employees (Warders) towards inmates and skills acquisition

\begin{tabular}{|c|c|c|c|c|}
\hline \multirow[t]{2}{*}{ Items } & \multicolumn{4}{|c|}{ Response } \\
\hline & & Yes & No & Total \\
\hline \multirow[t]{2}{*}{ Policy makers support effective programmers } & Frequency & 8 & 3 & 66 \\
\hline & $\%$ & 72.7 & 27.3 & 100.0 \\
\hline \multirow[t]{2}{*}{ One treat prisoners as people who have values } & Frequency & 8 & 3 & 66 \\
\hline & $\%$ & 72.7 & 27.3 & 100.0 \\
\hline \multirow{2}{*}{$\begin{array}{l}\text { Do you agree that inmates have the ability to } \\
\text { improve their potentials }\end{array}$} & Frequency & 8 & 3 & 66 \\
\hline & $\%$ & 72.7 & 27.3 & 100.0 \\
\hline \multirow{2}{*}{$\begin{array}{l}\text { Do you agree that inmates exposed to education do } \\
\text { not go back to previous offence? }\end{array}$} & Frequency & 6 & 5 & 66 \\
\hline & $\%$ & 54.4 & 45.5 & 100.0 \\
\hline \multirow[t]{2}{*}{ Averaged Total } & Frequency & 8 & 3 & 66 \\
\hline & $\%$ & 72.7 & 27.3 & 100.0 \\
\hline
\end{tabular}

Field Study, 2018

The findings on attitude of government and prison service employees (Warders) towards inmates' welfare were extracted from workers in the prison homes. Table 5 shows that majority of the responding workers $(72.7 \%)$ opined that Policy 
makers support effective programmers for inmates, while $27.3 \%$ felt contrary. It was also observed that $72.7 \%$ of the respondents agreed that one treat prisoners as people who have values, while $27.3 \%$ does not. It was indicated that majority of the responding workers $(72.7 \%)$ agreed that inmates have the ability to improve their potentials, while $27.3 \%$ did not. Lastly, $54.4 \%$ agreed that inmates exposed to education do not go back to previous offence, while $45.5 \%$ did not.

Conclusively, the average summary showed that the attitude of government and prison service employees (Warders) towards inmates general welfare, although, they might not have actually implemented somepolicies that would materialise the needs of such attitude, The responses was such that

$72.7 \%$ on the average indicated positive attitude on the side of the government and prison service employees towards inmates general welfare, while $27.3 \%$ did not.

\section{Discussion of Findings}

Research Question I sought to identify the age range of inmates in the prison yard. Findings of this research indicate that most the inmates were youths ranging between 2I and 30 years of age. The result is in line with the findings of Kabir (20I9) that there is high population of prisoners to be youths due to their inability to get someone or money to support then, thus forcing them to remain in prison for a long time, youths are also known to be fond of committing different crimes which always end them up in prison.

The findings of this research indicate some prisoners cherish societal valued life. This is in line with the view of some prisoners who pursued university certificate while in the prison like Kabiru (2017) a lifer that bagged master's degree in Business Administration stated he believed he would gain freedom later in life and be able to use his certificate.

The perceptions of inmates towards skill acquisition revealed they loved learning different skills which they believed would help them later in life. However the findings of this study is in agreement with Talba (2015); and Tenibaije (20I0) in Abubakkar \&Abba (2018) who mentioned different skills available in prison yards for inmates to rely upon after their release.

Findings under research question 4 , revealed the inmates perceived formal and literacy education to be important for them after their release. The findings are in line with those of Davies et al (20I4), Rand (20I3); Kabiru in Daily Punch, (2017): \& Daramola (2004) that inmates who took part in correctional educational programme do not always offend and be sent back to the prison compared with released inmates who did not participate in correctional education.

Findings under research question 5 indicated that prison service employees are of the view that

policy makers support effective programme for the inmates, while they believed inmates have values and ability to improve their potentials, this is in line with Rand (2013); Daramola(2004); Schiradi(2003); Mc clary (2003); \&Clemens (2003) that it is cheaper to reform and educate prisoners, and that prisons with education programmes have fewer violent incidents.

\section{Conclusion}

The findings of this study established that large populations of inmates are youths and as ex-convicts inmates cherish a societal valued life. It also indicated that convicted inmates engage themselves in vocational training; formal and literacy education so as to fit in to the society by depending on the knowledge they have acquired in the prison yard for survival.

\section{Recommendations}

Based on the discussions above, the following recommendations are put forward:

- Youths are advised to be conscious of not breaking the rules of Nigeria that could send them to prison. Inmates and ex -convict are to see themselves as being important and serving a jail sentence is not the end of one's life.

- Inmates that have not been tried are advised to engage themselves in productive activities until they are taken to court for trial

- Policy makers are advised to see the poor condition of the prison yards in terms of overcrowding in cells, poor health condition, and delay in trial of inmates.

- Policy makers to understand prison is for reformation, re-integration and but not to send inmates back to the society

\section{References} worse than going to jail.

Abubakar, K.H.\& Abba, M. (2018). Participation of prison inmates in vocational skills acquisition programme

For self-reliance and sustainable economic growth in Sokoto State, Nigeria. Review of European Studies IO (2) 2018.

Arnett, (2017) Committee www. archieve.pov.org assessed on I7-I-2018

Byrne, D. (2018). Prison reform www.reasons to be cheerful.

Clemens, D. (2003). Prison: To punish or to reform? Archieve.pov.org

Daramola V.A.O (2004), The administration of relief materials in prison.A paper presented at the workshop for social pastoral workers in the prison by JDPC, Ibadan.

Daily Punch, (2017). Inspiring tales of life prisoners piling up degrees. 
Davis, L.M, Steele, J.L., Bozick R., Williams, M.V., Miles, N.V., Saunders, J., Turner, S., Steinberg, P.S.,

(2014). Does providing inmates with education improve post release outcomes? A Meta-Analysis of

Correctional Education Programmes in United States. Journal of Experimental Criminology.

Department of Safety and Security Management, Tshwane University of

http://www.dailytrust.com.ng/daily/index.php/5267

Index.php/52674-

Job creation. International Journal of Education Research, I3(I), I28-I44 In

Kabiru, C. (2019). More than half of Nigerians awaiting trial- prisoners under age. Premium Times.

Kelowna, (201 I). www.dataangel.com

Kruidenier, J. (2002) Literacy education in Adult Basic Education: National Centre for the Study of Adult Learning and Literacy. Vol 3 www.ncsall.net

Mc Clary, T. (2003). National criminal justice representative, American friends service committee. www, archive .pov.org assessed on I7-I-2019

Nigerian Prison Service (2014). Prisons in Edo State, Nigeria. en.m.wikipedia.org: assessed I I February 2019

Obioha, E.E. (1995). Prison culture in Nigeria; A study of life within Agodi prison community, Ibadan. M.Sc Dissertation, Unpublished. Ibadan: Department of Sociology, University of Ibadan.

Obioha, E.E.(20II).Challenges and reforms in the Nigerian prisons system. Department of Safety and Security Management, Tshwane University of Technology, Pretoria, South Africa. Journal of SocialScience, 27(2) 95-109

Oloruntegbe. K.O. (20I4). Creating productive parental and community involvements in Science Education of youths. Akungba Journal of Research in Education. (2), I22-I38

Oreloye, A.K. (2018).Rehabilitation and welfare of inmates in Nigeria Prisons: A case of selected prisons in Southwestern Nigeria. Canadian Social Science. I4 (6). pp 78-86

Punch, (2015) Inspiring tales of life prisoners pilling up degrees. August 29, punching .com

Saturday Punch (2018). 30 Prison, inmates to die by hanging. Saturday Punch, May I2. . pov. org assessed on I7-I-2019

Schiraldi V. (2003), Founder and president of the justice policy institute www.pov.org

Social Science, I4(6), 78-86

Talba, A.M. (2015). Remembering the inmates of Kaduna Prison. Daily Trust News Paper Report, April, 22 Retrieved August, 2015 from http://www.dailytrust .com.ng/index. Php/52674

The Guardian (2008). What good is prison? www.the guardian.com assessed I7-I-2019

Whelan, R. (2004), Prisons are good for society. The telegraph www. telegraph.co.uk

\section{Copyrights}

Copyright for this article is retained by the author(s), with first publication rights granted to the journal. This is an open-access article distributed under the terms and conditions of the Creative Commons Attribution license (http://creativecommons.org/licenses/by/4.0/). 